\title{
HIGHLY ORIENTED CUBIC CRYSTALLINE PEROVSKITE THIN FILM OF METHYLAMMONIUM LEAD BROMIDE
}

\author{
AYI BAHTIAR* ${ }^{*}$ KHARIRUL HABIBIE, NABILA ASY SYIFA AND SETIANTO \\ Department of Physics, Universitas Padjadjaran \\ Jl. Raya Bandung-Sumedang Km.21 Jatinangor 45363, Sumedang, Jawa Barat, \\ Telp. 022-7796014 \\ *email : ayi.bahtiar@phys.unpad.ac.id
}

\begin{abstract}
Organic-inorganic lead halide perovskite materials have been intensively developed for variety optoelectronic applications including solar cells, light-emitting diode and photodetection due to their excellent properties including bandgap tunability, long charge carrier diffusion length, and outstanding optoelectronic merits. Recently, perovskite methylammonium lead bromide $\left(\mathrm{CH}_{3} \mathrm{NH}_{3} \mathrm{PbBr}_{3}\right.$ or $\left.\mathrm{MAPbBr}_{3}\right)$ has intensively studied for X-Ray detectors due to high stability against temperature and humidity and also has high X-Ray coefficient attenuation. Most of the perovskite-based optoelectronic devices are using thin films, whose their stability are highly depending on thin film morphology, including grain boundaries and crystal orientation. Morphological control, therefore, plays a significant role to produce high quality perovskite thin films. Thin films perovskite $\mathrm{MAPbBr}_{3}$ were prepared using spin-coating technique at room tempperature with $70 \%$ relative humidity. Its absorption spectra was measured using UV-Vis spectroscopy, its crystal structure using X-Ray Diffraction and morphology of thin films using Scanning Electron Microscopy (SEM). The optical bandgap of $\mathrm{MAPbBr}_{3}$ thin film is $2.23 \mathrm{eV}$ derived from its absorption spectrum. The film is very stable against humidity confirmed by unchange of its absorption spectrum after 24 hours stored at room temperature with $70 \%$ relative humidity. The film shows cubic crystal structure with lattice constant $5.99 \AA$ and high highly oriented in $\mathrm{x}$-axis. The SEM images show cubic crystallites with size larger than 2 micrometer. The morphology of thin film and crystallite size are influenced by adding ethylammonium iodide additive or anti-solvent chlorobenzene treatment.
\end{abstract}

Keywords: perovskite, $\mathrm{MAPbBr}_{3}$, thin film, X-Ray detectors, humidity, stability, morphology

\begin{abstract}
Abstrak. Material hybrid organik-inorganik perovskite timbal halida telah banyak dikembangkan untuk berbagai aplikasi optoelektronik termasuk sel surya, light-emitting diode dan detektor cahaya, karena sifatnya yang sangat unggul, meliputi energi gap yang bisa diatur, panjang difusi muatan pembawa yang panjang dan keunggulan sifat optoelektronika lainnya. Baru-baru ini, perovskite metilammonium timbal bromida $\left(\mathrm{CH}_{3} \mathrm{NH}_{3} \mathrm{PbBr}_{3}\right.$ atau $\left.\mathrm{MAPbBr}_{3}\right)$ telah banyak dikaji secara intensif untuk aplikasi detektor sinar-X, karena memiliki stabilitas yang tinggi terhadap temperatur dan kelembaban serta memiliki koefisien atenuasi X-Ray yang tinggi. Sebagian besar piranti optoelektronik berbasis perovskite menggunakan film tipis, yang stabilitasnya sangat tergantung pada morfologi film tipis, termasuk batas butir (grain) dan orientasi kristal. Oleh karena itu, kontrol morfologi memainkan peranan yang penting untuk menghasilkan film tipis perovskite berkualitas tinggi. Dalam penelitian ini, film tipis perovskite $\mathrm{MAPbBr}_{3}$ dibuat menggunakan teknik spin-coating pada temperatur kamar dengan kelembaban relatif $70 \%$. Spektrum absorbansi film tipis $\mathrm{MAPbBr}_{3}$ diukur menggunakan spektroskopi UVVis, struktur kristalnya menggunakan Difraksi Sinar-X (XRD) dan morfologi film tipis menggunakan Scanning Electron Microscopy (SEM). Celah pita optik atau bandgap film tipis $\mathrm{MAPbBr}_{3}$ diperoleh 2,23 eV. Film ini sangat stabil terhadap kelembaban yang dikonfirmasi dengan tidak berubahnya spektrum absorbansinya setelah 24 jam disimpan
\end{abstract}

JIIF (Jurnal Ilmu dan Inovasi Fisika), ISSN: 2549-0516 
pada temperatur kamar dengan kelembaban relatif 70\%. Film ini memperlihatkan struktur kristal kubik dengan konstanta kisi 5,99 A dan berorientasi pada sumbu x. Gambar SEM menunjukkan kristalit berbentuk kubik dengan ukuran lebih besar dari 2 mikrometer. Morfologi film tipis dan ukuran kristal dipengaruhi oleh penambahan aditif etilammonium iodida atau perlakuan anti-pelarut klorobenzen.

Kata kunci: perovskite, $\mathrm{MAPbBr}_{3}$, film tipis, detektor sinar-X, kelembaban, stabilitas, morfologi

\section{Introduction}

In the last decade, hybrid organic-inorganic perovskite $\mathrm{MAPbX}_{3}\left(\mathrm{MA}=\mathrm{CH}_{3} \mathrm{NH}_{3}{ }^{+}\right.$, $\mathrm{X}=$ halide ions $\mathrm{I}^{-}, \mathrm{Br}^{-}$and $\mathrm{Cl}^{-}$) have great interrest for optoelectronic applications, such as solar cells, light-emitting diodes, photoelectric detectors, and high energy X/Gamma-ray detectors [1-3]. These perovskite materials exhibit excellent optoelectronic properties, including large optical absorption, high charge carrier mobility, long charge carrier diffusion length, tunability in optical bandgap and large X-ray attenuation coefficient [3-5]. Perovskite $\mathrm{MAPbI}_{3}$ is the mostly used as active material for solar cells with high power conversion efficiency (PCE). Recently, a PCE above $25 \%$ has been obtained, which is comparable to the dominant market silicon solar cells [6]. However, low stability in particular to humidity hinders it to be mass produced and commercialized. $\mathrm{MAPbI}_{3}$ has tetragonal crystal structure with lattice constants $\mathrm{a}=\mathrm{b}=8.87 \AA$ and $\mathrm{c}=12.67 \AA$ at medium to room temperature $(\mathrm{T}=162-327 \mathrm{~K})$. It crystal structure changes with temperature. At low temperature $(\mathrm{T}<162 \mathrm{~K})$, it has orthorombic structure and changes to cubic at high temperature $(\mathrm{T}>327 \mathrm{~K})$ [7]. This unstablle crystal struture leads to low stability to temperature and humidity. Therefore, many efforts have been studied to improve the stability of $\mathrm{MAPbI}_{3}$, including repplacing MA with more stable Formamidium (FA), insertion small fraction of MA with inorganic Cesium ion forming $\mathrm{Cs}_{\mathrm{X}} \mathrm{MA}_{1-\mathrm{X}} \mathrm{PbI}_{3}$ and mixed halide iodide-bromide $\mathrm{MAPbBr}_{\mathrm{X}} \mathrm{I}_{3-}$ $\mathrm{x}[8,9]$.

Most of the perovskite-based optoelectronic devices such as photoelectric detectors and solar cells are using thin films, whose their stability are highly depending on thin film morphology, including grain boundaries, crystal orientation, and surface defects [10]. Morphological control is, therefore, play a significant role to produde high quality perovskite thin films for obtaining high performance optoelectronic devices [10]. For example, morphology of $\mathrm{MAPbI}_{3}$ thin films can be altered by adding anti-solvents either by mxing them into solution directly or by dropping them after thin film preparation. Recetly, Fei et al used small amount (2-3\%) of ethylammonium iodide (EAI), n-propylammonium iodide (PAI) and butylammonium iodide (BAI) cations into $\mathrm{MAPbI}_{3}$ solution as additives to improve the PCE and stability of solar cells. They showed that by adding small amount of additive, both the PCE and stability of solar cells against humidity with 45-50\% are higher than that of untreared perovskite solar cells. The PCE and stability is increased by adding EAI, BAI and PAI, respectively [11]. Addition of small amounts of cations, can passivate the grain boundaries and film surface, can improve the grain size in both the lateral and vertical direction, crystal preferential orientation, and suppress the recombination, ultimately improving device efficiency. This passivation can prevent moisture diffusion, thus enhancing device stability. Other study done by Kong et al used a small drop of chlorobenzene (CB) during thin film preparation of perovskite. They dropped small amount of CB just after 30$40 \mathrm{~s}$ first spin-coating process and then continued to spin-coating for $20 \mathrm{~s}$. They 
showed that anti-solvent treatment using chlorobenzene (CB) promoted a perovskite film with highly smooth surfaces and enlarged grain sizes. As consequency, solar cells fabricated from CB treated perovskite film achieved a best PCE of $15.80 \%$, in comparison with $14.02 \%$ for the untreated device [12].

One of the perovskite material that showed high stability against high humidity is methylammonium lead tri-bromide or $\mathrm{MAPbBr}_{3}$ [13]. However due to its large optical bandgap $(\sim 2.2 \mathrm{eV}), \mathrm{MAPbBr}_{3}$ based solar cells showed smaller PCE than that of $\mathrm{MAPbI}_{3}$ [14]. Many groups have been using $\mathrm{MAPbBr}_{3}$ both in the form of thin films and single crystals for photoelectric and X-ray detectors rather than for solar cells application, due to its high stability against humidity [3]. Morphologycal and crystal orientation is highly needed for detectors application. Therefore, in this study, we prepared thin perovskite $\mathrm{MAPbBr}_{3}$ using spin-coating at ambient with humidity higher than $70 \%$. We measured optical absorbance of thin films using UV-Vis spectroscopy and its crystal structure using X-Ray Diffraction (XRD). The film show highly cubic crystalline and highly oriented in X-axis. We also used antisolvent $\mathrm{CB}$ for thin film treatment and additive EAI to $\mathrm{MAPbBr}_{3}$ solution to study their influence on thin film morphology of $\mathrm{MAPbBr}_{3}$. The morphology of untreated and treated thin films were measured using Scanning Electron Microscopy (SEM).

\section{Materials and Methods}

Methylammonium bromide (MABr $>99 \%)$, lead bromide $\left(\mathrm{PbBr}_{2}, 99.999 \%\right)$ were purchased from Lumtec Technology Corp. Taiwan. Ethylammonium iodide (EAI) and Dimethylformamide (DMF) were purchased from Sigma Aldrich. All materials are used as received directly without any further purification.

$\mathrm{MAPbBr}_{3}$ solution was carried out by mixing $112 \mathrm{mg} \mathrm{MABr}$ and $461 \mathrm{mg} \mathrm{PbBr}_{2}$ in $1 \mathrm{~mL}$ DMF. The solution was then stirred with magnetic stirrer at $300 \mathrm{rpm}$ while heated at a temperature of $70^{\circ} \mathrm{C}$ for 30 minutes. The solution was then centrifuged at $300 \mathrm{rpm}$ for 15 minutes. Perovskite thin films were prepared by spin-coating technique of solution on substrate at $5000 \mathrm{rpm}$ for UV-Vis spectroscopy measurements, while for XRD film measurements the films were spin-coated at $1000 \mathrm{rpm}$. Thin films preparation using EAI additive was prepared by adding 3\% of EAI into $\mathrm{MAPbBr}_{3}$ solution. The solution and thin film preparation were done with the same way as untreated $\mathrm{MAPbBr}_{3}$ thin film preparation, as described previously. While, for anti-solvent treatment, the small volume (around 20 microliter) of $\mathrm{CB}$ was dropped and spin-coated just $40 \mathrm{~s}$ after spin-coating of $\mathrm{MAPbBr}_{3}$ solution. After the spin-coating process, the perovskite film was heated on a hot plate at $70^{\circ} \mathrm{C}$ for 60 minutes. Thin perovskite films for UV-Vis spectroscopy measurement were spin-coated on quartz substrate, while for XRD measurements, thin films were spin-coated on glass substrate. Powder $\mathrm{MAPbBr}_{3}$ was obtained by grinding large crystals that was previously prepared by inverse temperature crystallization (ITC) method [15].

$\mathrm{UV}-\mathrm{Vis}$ absorbance spectra of thin films were carried out using $\mathrm{T} 70+\mathrm{UV} / \mathrm{V}$ is spectrometer at the Material Physics Laboratory, Department of Physics, Universitas Padjadjaran. XRD measurements were conducted using X-ray Diffraction PANalytical X'Pert PRO 40 kV 30 mA PW3040/x0 Cu-Ko with wavelength $1.54 \AA$ at Pusat Survey Geology Bandung. 


\section{Results and Discussion}

Optical absorbance spectrum of thin film $\mathrm{MAPbBr}_{3}$ is shown in Figure 1. It has absorption wavelength ranging from UV to $500 \mathrm{~nm}$. The inset shows the determination of cut-off wavelength to calculate the optical bandgap $\left(E_{g}\right)$ using equation.

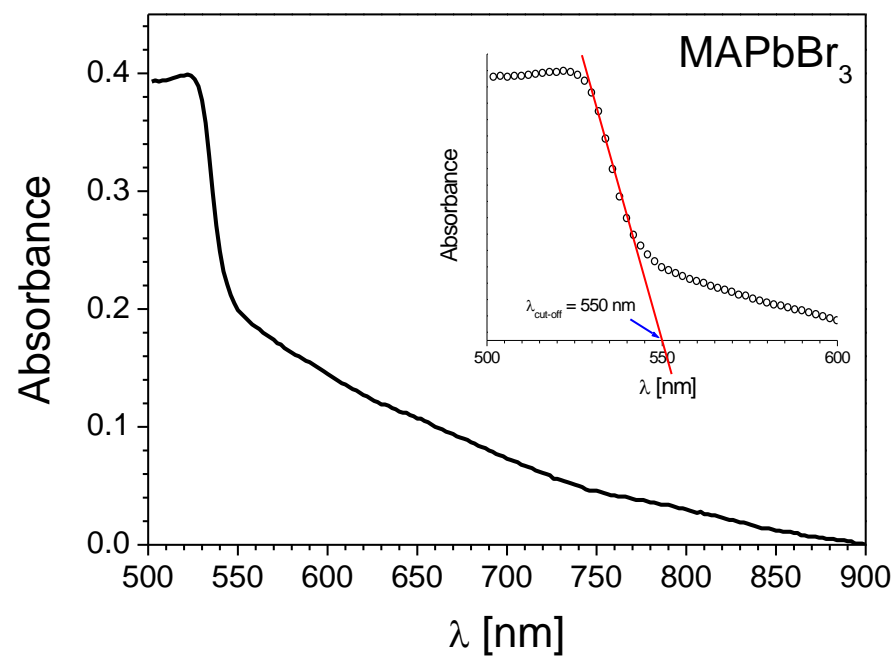

Figure 1. Optical absorbance of fresly prepared thin film perovskite of MAPbBr3. Inset is the determination of cut-off wavelength for optical bandgap calculation

$$
E_{g}=\frac{h c}{\lambda_{c u t t-o f f}}
$$

where $\mathrm{h}$ is Planck's constant $\left(6.626 \times 10^{-34} \mathrm{~m}^{2} . \mathrm{kg} / \mathrm{s}\right), \mathrm{c}$ is speed of light in vacuum $(3 \times 108 \mathrm{~m} / \mathrm{s})$ and and $\lambda_{\text {cut-off }}$ is the cut-off wavelength obtained by drawing a slope line or intersection between the $\mathrm{x}$-axis (wavelength) and the $\mathrm{y}$-axis (absorbance). The optical bandgap of $2.23 \mathrm{eV}$ is obtained. It is very close to the calculated bandgap value reported by Noh et al, who studied the optical bandgap of mixed halide perovskite $\mathrm{MAPb}\left(\mathrm{I}_{1-\mathrm{X}} \mathrm{Br} \mathrm{x}_{3}\right)_{3}$ with $\mathrm{x}$ was varied from 0 to 1 [13]. They obtained the relation between $\mathrm{x}$ and $\mathrm{E}_{\mathrm{g}}$ as:

$$
E_{g}(\mathrm{eV})=1.57+0.39 x+0.33 x^{2}
$$

which is $\mathrm{E}_{\mathrm{g}}$ of $2.29 \mathrm{eV}$ for $\mathrm{MAPbBr}_{3}(\mathrm{x}=1)$. The higher optical bandgap $\mathrm{E}_{\mathrm{g}}$ of $\mathrm{MAPbBr}_{3}$ as compared to $\mathrm{MAPbI}_{3}$, leads to unsuitable it as active material for producing high PCE solar cells. Therefore, this perovskite is now mostly used for other applications, in particular for X-ray detectors due to high X-ray attenuation coefficient $[3,15]$.

Figure 2 shows absorption spectra of thin films $\mathrm{MAPbBr}_{3}$ measured just after thermally annealing process (as-prepared, $0 \mathrm{~h}$ ) and after 24 hours stored in ambient air at room temperature $\left(\mathrm{T}=27^{\circ} \mathrm{C}\right)$ with $70 \%$ relative humidity. The spectra do not show any significant changes in absorption and also no changes in the cut-off wavelength is observed. It means that the optical bandgap is not changed due to humidity. This results prove that $\mathrm{MAPbBr}_{3}$ thin film is very stable against $70 \%$ relative humidity. On the contrary, a significant change in absorption spectrum of 
$\mathrm{MAPbI}_{3}$ was observed by Smith et al when the film was stored at ambient with $52 \%$ relative humudity. The spectrum changes to absorption spectrum of $\mathrm{PbI}_{2}$ after stored for 40 days [16]. The unstable $\mathrm{MAPbI}_{3}$ leads to decreasing of the PCE of solar cells with time $[8,16]$.

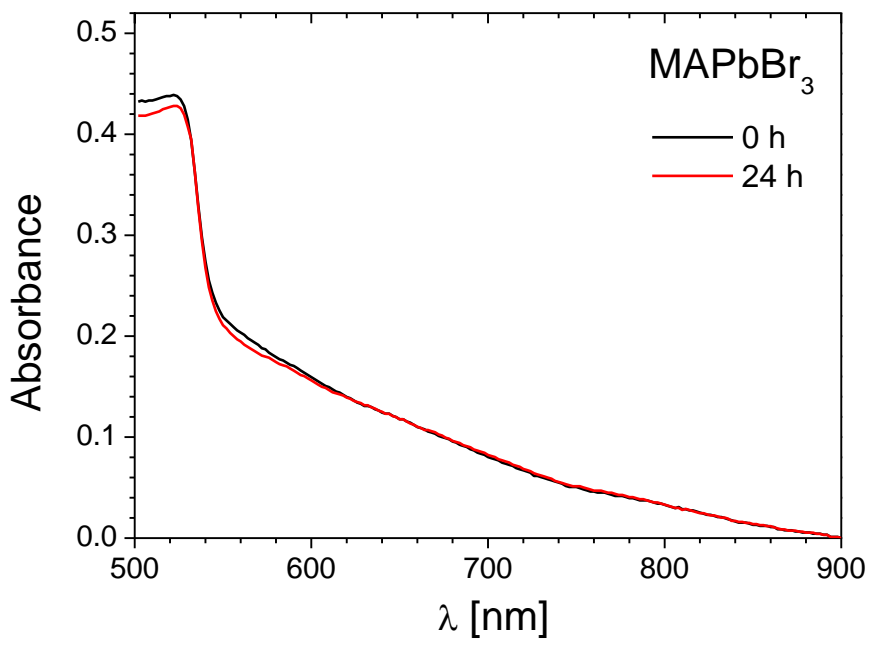

Figure 2. Optical absorbance of thin film perovskite $\mathrm{MAPbBr}_{3}$ as prepared $(0 \mathrm{~h})$ and after 24 hours stored in ambient at room temperature $\left(\mathrm{T}=27^{\circ} \mathrm{C}\right)$ with $70 \%$ relative humidity

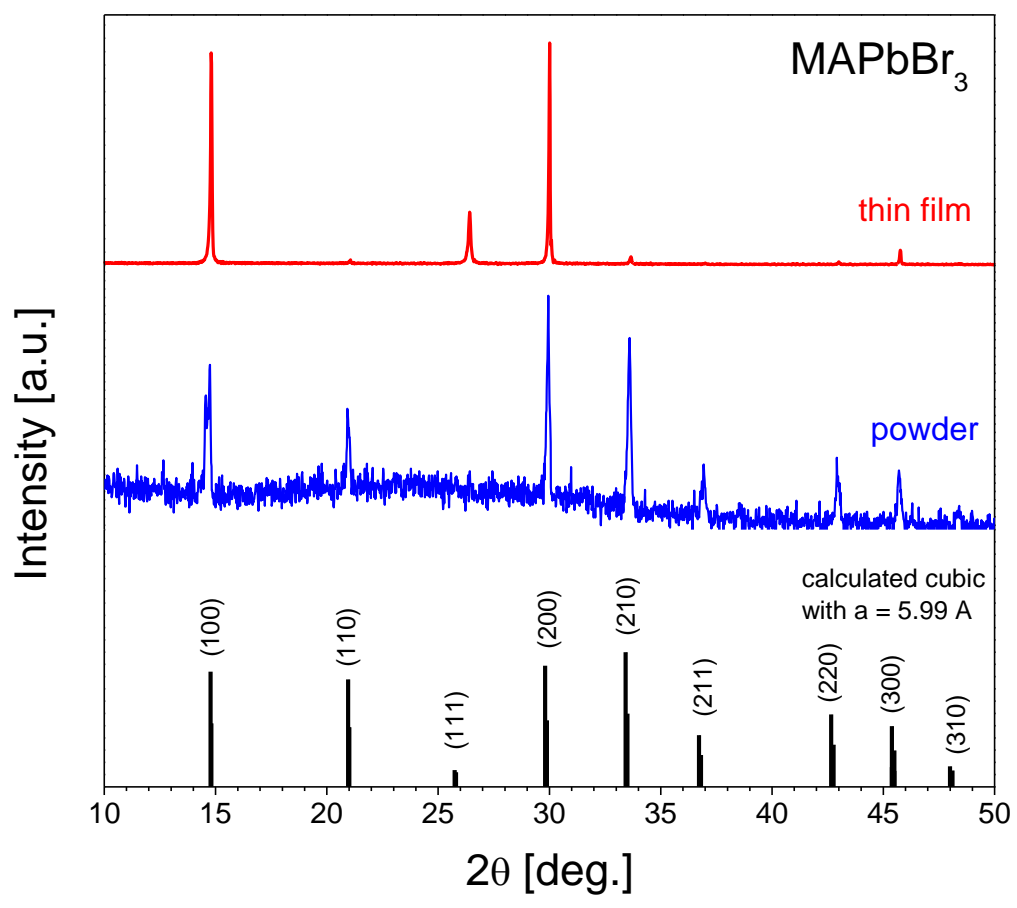

Figure 3. XRD patterns of $\mathrm{MAPbBr}_{3}$ powder, thin film and calculated using cubic crystal structure with lattice constant $5.99 \AA$

XRD patterns of calculated perovskite cubic crystals structure using lattice constant $\mathrm{a}=5.99 \AA$, powder and thin film of $\mathrm{MAPbBr}_{3}$ are shown in Figure 3. The XRD pattern of $\mathrm{MAPbBr}_{3}$ powder is exactly matched with the calculated XRD pattern, 
which shows that $\mathrm{MAPbBr}_{3}$ has cubic crystal structure. Seven diffraction peaks are observed at angles $14.70^{\circ}, 20.92^{\circ}, 29.95^{\circ}, 33.60^{\circ}, 36.92^{\circ}, 42.92^{\circ}$ and $45.70^{\circ}$ that are related to the peaks of (100), (110), (200), (210), (211), (220) and (300) crystal planes, respectively. This XRD pattern agrees very well with reported data by Wang et al, which showed that $\mathrm{MAPbBr}_{3}$ has a cubic crystal structure with a $\mathrm{Pm} 3 \mathrm{~m}$ space group [17]. There is no diffraction peak that originates from $\mathrm{PbBr}_{2}$ (at $18.61^{\circ}$ ), meaning that all $\mathrm{PbBr}_{2}$ is converted into perovskite $\mathrm{MAPbBr}_{3}$. Moreover, the XRD pattern shows that the crystal plane is predominantly oriented toward the $\mathrm{x}$-axis, indicated by two dominant high diffraction peaks at $14.70^{\circ}$ and $30.00^{\circ}$ related to the peak of (100) and (200) planes. Only two small peaks with x-y axis crystal plane orientation are observed. This XRD pattern shows that $\mathrm{MAPbBr}_{3}$ thin film is highly crystalline with cubic crystal structure and highly oriented in $\mathrm{X}$-axis. The cubic structure is also confirmed with SEM measurement of thin film.

SEM images of surface thin films $\mathrm{MAPbBr}_{3}$ untreated, using anti-solvent $\mathrm{CB}$ treatment and adding EAI additive are shown in Figure 4. All images show cubic form as confirmed from XRD measurement. The image of untrated film show shows compact and tight cubic crystallites with clear crystallite boundaries [Figure 4(a)]. The size of crystallite is larger than 2 micrometer.

The use of anti-solvent CB during thin film preparation stretches the distance between crystallites, but it has still cubic form. The size of crystallite is 1 micrometer, smaller than that of untreated film, but the size of crystallite is more homogen [Figure 4(b)]. The addition of EAI did not change the cubic of crystallite but with more heterogenous in size [Figure 4(c)]. From these SEM images, we can learn that the morphology of perovskite $\mathrm{MAPbBr}_{3}$ thin film strongly depends on the preparation of thin films.
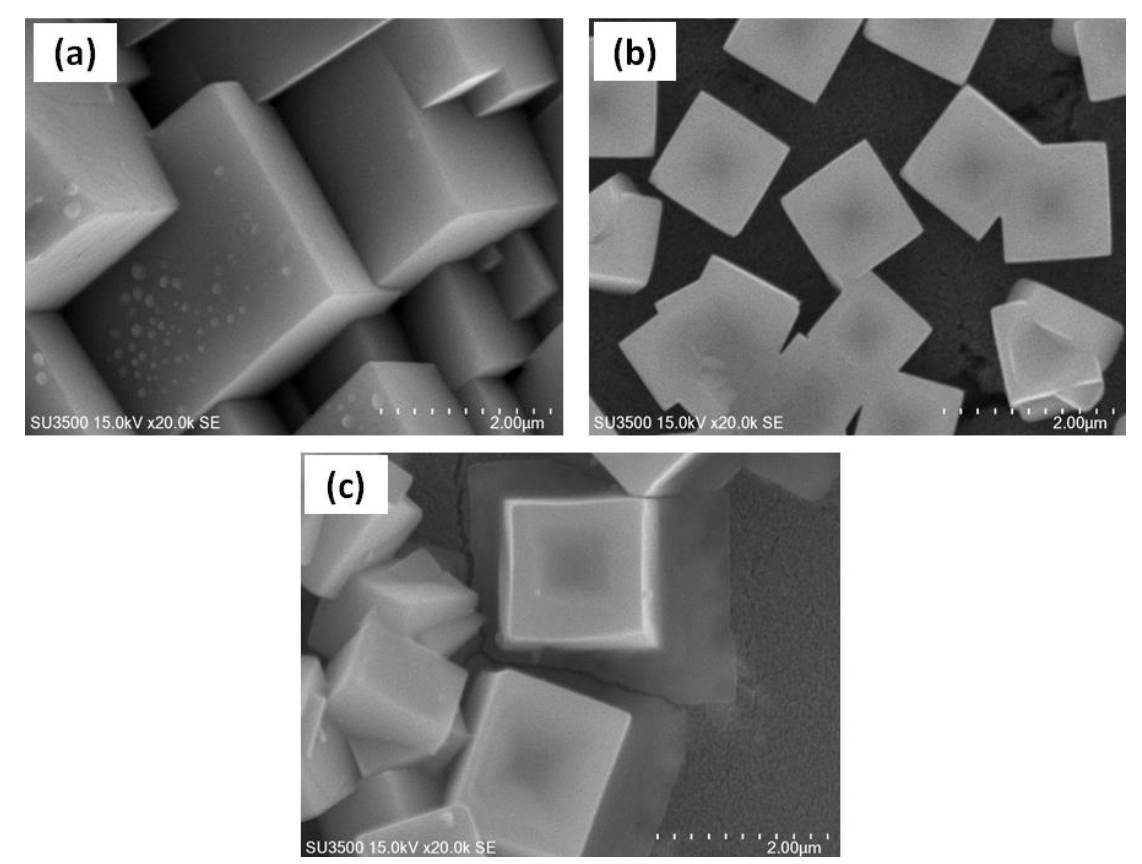

Figure 4. SEM images of $\mathrm{MAPbBr}_{3}$ thin films (a). Untreated, (b). With antisolvent CB treatment and (c). Using EAI additive 


\section{Conclusions}

We have succesfully prepared highly crystalline and highly oriented thin perovskite film of $\mathrm{MAPbBr}_{3}$. The optical bandgap of $2.23 \mathrm{eV}$ is obtained. The film is very stable against $70 \%$ relative humidity. The XRD measurement shows that the film shows cubic crystal structure with lattice constant 5.99 $\AA$ as also confirmed by SEM images. The crystal plane is highly oriented in X-axis. The SEM images show cubic crystallites with size larger than 2 micrometer. The morphology of thin film and crystallite size are influenced by adding EAI additive or anti-solvent CB treatment.

\section{Acknowledgement}

This research is financially supported by Hibah Internal Universitas Padjadjaran (HIU) scheme Riset Kompetensi Dosen Unpad (RKDU), Contract No. 1427/UN6.3.1/LT/2020, dated on April, 09, 2020.

\section{References}

1. M. I. H. Ansari, A. Qurashi, M. K. Nazeeruddin, Frontiers, opportunities, and challenges in perovskite solar cells: A critical review, Journal of Photochemistry and Photobiology C: Photochemistry Reviews, Vol. 35 (2018), pp. 1-24.

2. J. Sun, J. Wu, X. Tong, F. Lin, Y. Wang, Z.M. Wang, Organic/inorganic metal halide perovskite optoelectronic devices beyond solar cells, Advanced Science, Vol. 5 (2018), 1700780 (13 pages).

3. L. Gao, Q. Yan, Recent advances in lead halide perovskites for radiation detectors, RRL Solar, Vol. 4 (2020), 1900210 (12 pages).

4. W.S. Yang, B.-W. Park, E.H. Jung, N.J. Jeon, Y.C. Kim, D.U. Lee, S.S. Shin, J. Seo, E.K. Kim, J.H. Noh, Iodide management in formamidinium-leadhalide-based perovskite layers for efficient solar cells, Science, Vol. 356 (2017), pp.1376-1379.

5. S.D. Stranks, G.E. Eperon, G. Grancini, C. Menelaou, M.J. Alcocer, T. Leijtens, L.M. Herz, A. Petrozza, H.J. Snaith, Electron-hole diffusion lengths exceeding 1 micrometer in an organometal trihalide perovskite absorber, Science, Vol. 342 (2013), pp. 341-344.

6. National Renewable Energy Laboratory Best Research-Cell Efficiency Chart. Available online: https://www.nrel.gov/pv/assets/pdfs/best-research-cellefficiencies.20200406.pdf (accessed on June 1, 2020).

7. F. Brivio, J. M. Frost, J. M. Skelton, Lattice dynamics and vibrational spectra of the orthorhombic, tetragonal, and cubic phases of methylammonium lead iodide, Phyical Review B, Vol. 92 (2015), 144308 (8 pages).

8. R. Wang, M. Mujahid, Y. Duan, Z.-K. Wang, J. Xue, Y. Yang, A Review of perovskites solar cell stability, Advanced Functional Materials, Vol. 29 (2019), 1808843 (25 pages).

9. Z. Wang, Z. Shi, T. Li, Y. Chen, W. Huang, Stability of perovskite solar cells: A prospective on the substitution of the A cation and $X$ anion, Angewandte Chemie International Edition, Vol. 56 (2017), pp. 1190-1212. 
10. L. Zheng, D. Zhang, Y. Ma, Z. Lu, Z. Chen, S. Wang, L. Xiao, Q. Gong, Morphology control of the perovskite film for efficient solar cells, Dalton Transactions, Vol. 44 (2015), pp. 10582-10593.

11. C. Fei, M. Zhou, J. Ogle, D.-M. Smilgies, L. W. Brooks H. Wang, Selfassembled propylammonium cations at grain boundaries and the film surface to improve the efficiency and stability of perovskite solar cells, Journal of Materials Chemistry A, Vol. 7 (2019), pp. 23739-23746.

12. M. Kong, H. Hub, K. Egbo, B. Dong, L. Wand. S. Wang, Anti-solvent assisted treatment for improved morphology and efficiency of lead acetate derived perovskite solar cells, Chinese Chemical Letters, Vol. 30 (2019), pp. 13251328.

13. J. Noh, S. Im, J. Heo, T. Mandal, S. Seok, Chemical management for colorful, efficient, and stable inorganic-organic hybrid nanostructured solar cells, Nano Letters, Vol. 13 (2013), pp. 1764-1769.

14. N. J. Jeon, J. H. Noh, W. S. Yang, Y. C. Kim, S. Ryu, J. Seo, S. I. Seok, Compositional engineering of perovskite materials for high-performance solar cells, Nature, Vol. 517 (2016), pp. 476-480.

15. Y. Liu, Y. Zhang, Z. Yang, J. Feng, Z. Xu, Q. Li, M. Hu, H. Ye, X. Zhang, M. Liu, K. Zhao, S. Liu, Low-temperature-gradient crystallization for multi-inch high-quality perovskite single crystals for record performance photodetectors, Materials Today, Vol. 22 (2019), pp. 67-75.

16. I. C. Smith, E. T. Hoke, D. Solis-Ibarra, M. D. McGehee, H. I. Karunadasa, A layered hybrid perovskite solar-cell absorber with enhanced moisture stability, Angewandte Chemie International Edition, Vol. 53 (2014), pp. 11232-11235.

17. K. H. Wang, L. C. Li, M. Shellaiah, Kien Wen Sun, Structural and photophysical properties of methylammonium lead tribromide (MAPbBr 3 ) single crystals, Scientific Reports, Vol. 7 (2017), 13643 (14 pages). 